\title{
Copper Plate, an Ancient Egyptian Antibacterial Used to Protect the Pharaonic Mummies.
}

\section{Dr.Hesham Abbas Kamally}

\author{
Dr.Abrahim Badr»
}

\section{ABSTRACT}

In ancient Egypt, life after death was an enormous part of the Egyptian life. Thus the protecting bodies from decay and preserving them in a recognizable form was extremely important for the ancient Egyptians, who believed that people needed their bodies in the afterlife. From here started the mummification process, embalming and treating a dead body after death in ancient Egypt removed the internal organs from an incision on the left side of the mummy body, and covered with plate from copper or copper alloys. The results reveal that decorated bronze plate was used for protection and fights the decay of mummy body from microbial and fungal. Copper ions, either alone or in copper complexes, have been used for centuries to disinfect liquids, solids and human tissue. This manuscript explain the antibacterial mechanisms of bronze and the current usages of copper and copper alloys as antibacterial and antifungal by the ancient Egyptian to protect the body of mummies from decay. The study results suggest the selection of copper and tin alloy (bronze) plates can materially assist in reducing the transmission of infectious organisms and consider as excellent antibacterial action against several type of bacteria such as Bacillus, Pseudomonas and E. coli.

\footnotetext{
- Restoration Department, High Institute of Tourism, Hotel Management and Restoration, Alexandria,egypt.

- Restoration Department, High Institute of Tourism, Hotel Management and Restoration, Alexandria,egypt.
} 


\section{دراسات في آثار الوطن العربي بـ 1}

\section{1-Introduction}

The Egyptians believed that life after death was the greatest accomplishment of all. Therefore, the people of Egypt would spend most of their time preparing for the cross-over between life and death. Thus, protecting the bodies by mummification process from decay and preserving them in a recognizable form was extremely important, as they believed that people need their bodies in the afterlife. Mummification process started after an Egyptians death, they would be taken to a tent know the "tent of purification", here is where the mummification process was performed by embalmers. The first step to the process was to clean and wash the Egyptians life away with water from the Nile. From here the internal organs were removed from an incision on the left side of the body. The incision on the left side Fig. (1A) was then covered with either wax, or with a metal plate Fig. (1B). Copper plate was used for protection the body of mummy and decorated with magical symbols.

Copper or copper alloys were an important metal for the ancient Egyptians, because it could be easily worked and shaped into weapons, tools and magical plates. The metal and its alloys have been used as natural antimicrobial materials from the ancient time In ancient Egypt (2000 BC), copper was used to purify water and wounds. Copper sulphate for example was an especially important compound in early times. Ancient Egyptians used it as prescription for pulmonary diseases and a mordant in their dyeing process. Copper pipes and vessels were used to keep drinking water pure in ancient Egypt. The Roman people were used the copper cooking utensils to prevent the spread of disease. Also, the ancient Greeks in the time of Hippocrates (400 BC) prescribed copper for pulmonary diseases and for purifying drinking water. In India, several advices say that drinking water should be kept in copper vessels and

2) Dollwet HHA, Sorenson JRJ., 2001. Historic uses of copper compounds in medicine. Trace Elements Med 2: 80-7. 


\section{دراسات في آثار الوطن العربي بr 1}

exposed to sunlight to purify the water. The Aztec people (groups of central Mexico), used copper oxide and copper carbonate for treating skin conditions. Hindu devotees drink a "Holy water", stored in copper utensils as it keeps the water sparkling clean. In addition, the American pioneers put copper coins in wooden water casks to provide safe drinking water for their long journey. While, Japanese soldiers put pieces of copper in their water bottles to prevent spread of disease such as dysentery. The fungicidal and biocidal properties of copper were demonstrated in controlled laboratory studies starting in the early $1950 \mathrm{~s}^{r}$ and since then copper and copper compounds have been shown to effectively kill a wide range of fungi such as Aspergillus carbonarius'. Scientists are also actively demonstrating the intrinsic efficacies of copper alloy "touch surfaces" to destroy a wide range of microorganisms that threaten public health. Copper exerts its toxicity to microorganisms through several parallel mechanisms, which eventually may lead to the microorganisms' death even within minutes of their exposure to copper $^{\text {¿ }}$. Copper is also used as the active ingredient in products that prevent roof moss formation, such as copper granules found in

3M Scotchgard Algae Resistant Roofin System

This paper interpretation the potent biocidal properties and the current usages of copper and copper compounds as antibacterial and antifungal agents in ancient Egypt.

3) Foye Wo, Van De Workeen IB Jr, Matthes JD.,1958.Copper complexes of aromatic dithiocarbamates and their antifungal activity. J Am Pharm Assoc Am Pharm Assoc (Baltim) 47: 556-8.

4) Belli N, Marin S, Sanchis V, Ramos AJ., 2006. Impact of fungicides on Aspergillus carbonarius growth and ochratoxin A production on synthetic grape-like medium and on grapes. Food Addit Contam 23: 1021-9.

5) Ohsumi Y, Kitamoto K, Anraku Y.,1988.Changes induced in the permeability barrier of the yeast plasma membrane by cupric ion. J Bacteriol170: 2676-82.

6) Resistant Roofing System, 2004.http:// solutions.3m. com/ wps/portal/3M/en_US/IMPD/Roofing-Solutions/Products/Scotchgard-Algae- Resistant 

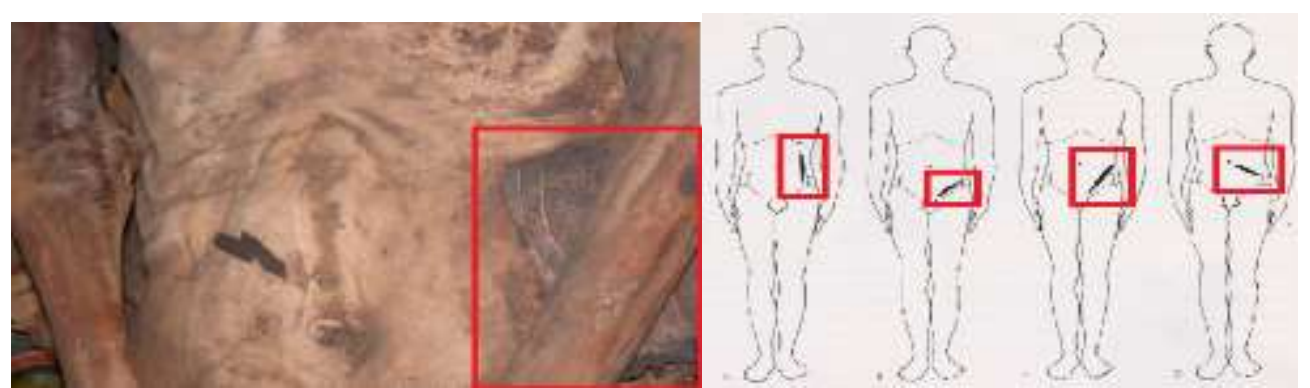

Fig.(1A)The mummified body with an incision in the left side and covered it with a metal plate.(B) Position of the incision, varied only slightly throughout ancient Egyptian history.

\section{2-Materials and methods}

Samples of the metal plate were studied by scanning electron microscope SEM-EDX and X-ray diffraction (XRD) to find their mineral composition, alteration products and morphological features of metal plate. Optical microscopy at various magnification degrees, up to maximum $100 \mathrm{X}$, was used to investigate the morphological forms and concentration of bacterial and fungal colonies. Scanning electron microscopy (SEM) together with energy dispersive spectrometer (EDX), was used to determine the type of alloy, morphology and the elemental composition. SEM micrographs and EDS spectra of selected specimens were obtained by using a JEOL JSM-5300 instrument, equipped with a Link EDX operated at accelerating voltage $30 \mathrm{KV}$. XRD analysis was used to identify type of alloy and the corrosion products covering the surface and to understand the corrosive conditions that led to the corrosion of the metal plate. The powder diffraction patterns of the samples were obtained $\mathrm{Cu}-\mathrm{k} \alpha$ radiation and $\mathrm{Ni}$ filter. The scanning speed is $2 \theta-1$ degree $/ \mathrm{min}$ at constant voltage $40 \mathrm{KV}$ and $30 \mathrm{Ma}$ using a Phillips PW 1840 diffractometer.

\section{3- Result and Discussion}

\section{3-1 Preparation of microbial media}

In this study two differential cultural media were used to microorganisms cultivation as follows:

1-Nutrient agar typically contains, $3 \mathrm{mg}$. peptone, $15 \mathrm{mg}$.agar-agar, $5 \mathrm{mg}$. $\mathrm{NaCl}, 3 \mathrm{gm}$. meat extract and $1000 \mathrm{ml}$. distilled water. 
2-Dox's agar medium consists of sucrose 20gm., 20mg.agar-agar, sodium nitrate $2 \mathrm{gm}$., dipotassium phosphate $1 \mathrm{gm}$., potassium chloride $0.5 \mathrm{mg}$., magnesium sulphate $0.5 \mathrm{mg}$. and $1000 \mathrm{ml}$. water tap. Sterilized by autoclaving at 105 atmospheric pressure at a temperature of $121^{\circ} \mathrm{C}$. Both nutrients were obtained from S.C.A (Supreme Council of Antiques) laboratories in Cairo- Egypt.

Several samples were taken under sterile conditions with swabs and scalpels from hair, mouth, shoulder and skins of Egyptian mummies. These samples were inoculated on Petri dishes with nutrient agar and dox's agar medium at $30{ }^{\circ} \mathrm{C}$. Numerous different bacterial and fungal colonies appeared on all Petri dishes. Pure cultures for identification were obtained from various morphological forms. The following species were identified and isolated: Asp. Niger, Asp. Fumigates, Asp. Flavus, Penicillium chrysogenum, Penicillium citrinum, Aspergillus japonicas, Asp. Wentii, Asp. Sulphureous and Pen. Citrinum Fig.(2).

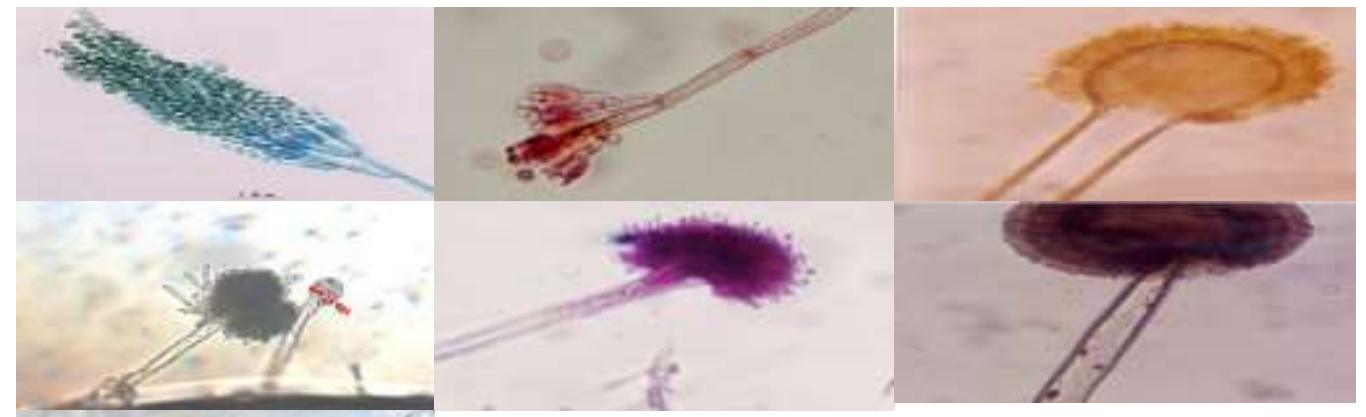

Fig.(2) Several bacterial and fungal species were identified APenicillium citrinum, B-Pen. Chrysogenum C-Asp. FumigatesDAsp. Japonicas, E- Asp. Flavus, g. Asp.Niger, F- Asp. Sulphoreus. 


\section{دراسات في آثار الوطن العريبي بـ 1}

\section{3- Antibacterial study of copper and tin alloy plates}

The results from previous biologic swabs reveal that several bacterial and fungal species were identified. These bacterial and fungal were cultivated with Dox's agar medium in Petri dishes in the absences of copper plates (sample A) Fig.(3) while in other Petri dishes the same bacterial and fungal were cultivated with Dox's agar medium in the presence of copper and tin alloy (bronze) plates (sample B). The antibacterial activities of the bronze plates were tested qualitatively and quantitatively by an inhibition zone method and a viable cell count method respectively. For qualitative measurement of antimicrobial activity, the bronze plates put together with various bacterial and fungal in Petri dishes and the antimicrobial activity was tested. Petri dishes were examined for possible clear zone after incubation at $30^{\circ} \mathrm{C}$ for 2 days. The presence of any clear zone around the bronze plates on the Petri dishes was recorded as an inhibition against the microbial species. To examine the bacterial growth or killing kinetics (quantitative measurement) bacterial and fungal were grown in Dox's agar supplemented with bronze plates at $30{ }^{\circ} \mathrm{C}$ for a period ranging between 7-21 days. Growth and killing rates or bacterial and fungal concentrations were determined on counting slide. Fig.(4) shows the bacterial colonies growth of all samples in Petri dishes in the absences and presence of bronze plates. In absence of bronze plates the continuous growth of bacterial cells were observed while in presence of bronze plates the bacterial growth is suppressed to a great extent due to strong killing kinetic action of $\mathrm{Cu}$ II ions which released from bronze plates. Consequently, bronze plates are very effective in killing bacterial cells. The results in Table (1) show the quantitative measurements of bacterial and fungal at $30{ }^{\circ} \mathrm{C}$ for a period ranging between 7-21 days. These results are represented in histogram diagram in Fig.(4). The diagram shows the growth of bacterial and fungal on dish plates in the absence and presence of bronze plates. These results reveal that all types of bacterial and 
fungal in absence bronze plates show high concentrations (dish A) while, in the presence of bronze plates (dish B) show low concentrations of bacterial and fungal.

Table (1) shows the concentration of bacterial and fungal for a period ranging from one week

\begin{tabular}{|c|c|c|c|c|c|c|}
\hline \multirow{2}{*}{$\begin{array}{c}\text { Types of bacterial and } \\
\text { fungal }\end{array}$} & \multicolumn{3}{|c|}{ Dish A } & \multicolumn{3}{|c|}{ Dish B } \\
\hline & Week 1 & Week 2 & Week 3 & Week 1 & Week 2 & Week \\
\hline Asp.Fumigatus & 1 & 1.8 & 2.15 & 1 & 1.3 & 1.7 \\
\hline Asp.Niger & 0.8 & 1.5 & 1.9 & 0.7 & 0.9 & 1.1 \\
\hline Asp.Flavus & 0.8 & 1.2 & 2.3 & 0.7 & 0.8 & 1.4 \\
\hline Aspergillus Japonicus & 1.5 & 2.4 & 2.6 & 1.4 & 2.0 & 2.1 \\
\hline Pen.Citrinum & 1 & 2 & 2.1 & 1 & 1.4 & 1.9 \\
\hline Asp.Sulphureous & 1 & 1.8 & 2.6 & 0.6 & 1.3 & 2.1 \\
\hline Asp. Wetii & 1 & 2.2 & 3.2 & 0.7 & 1.7 & 1.9 \\
\hline $\begin{array}{c}\text { Penicillium } \\
\text { Chrysogenum }\end{array}$ & 1 & 2 & 2.8 & 0.9 & 1.9 & 2.1 \\
\hline
\end{tabular}

to three week at $30^{\circ} \mathrm{C}$.

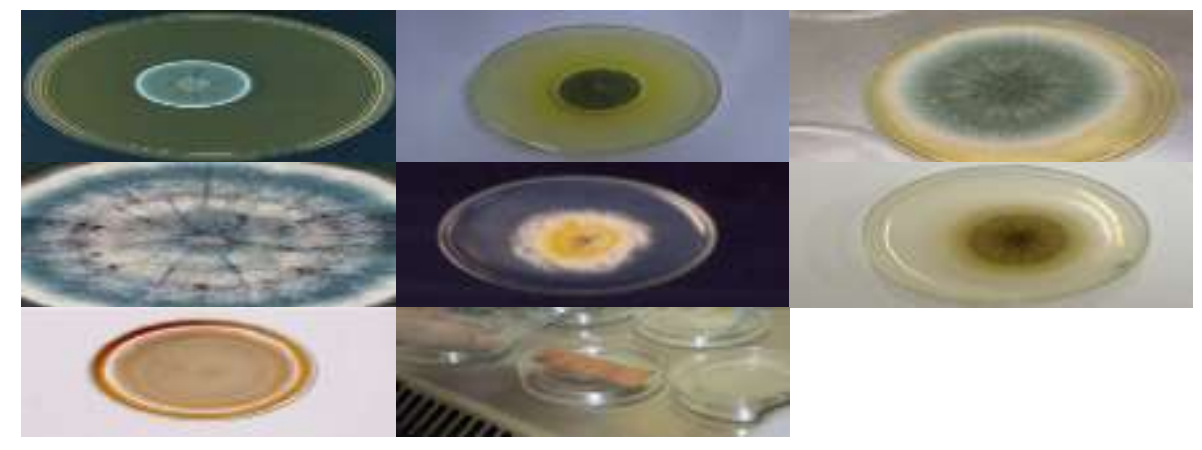

Fig.(3) shows the bacterial and fungal colonies growth with Dox's agar medium in Petri dishes in the absences (sample A)and presence of bronze plates (sample B).

The mechanism of biocidal action of bronze plates may probably be explained on the basis of the fact that bronze plates release $\mathrm{Cu}$ (II) ions on contact with moisture. These copper ions bind with the $-\mathrm{SH}$ and $-\mathrm{COOH}$ groups of protein molecules of bacterial cell wall and destroyed them. The 3-dimensional structure of proteins can be altered by copper, so that the proteins can no longer perform their 
normal functions. The result is inactivation of bacteria or viruses ${ }^{6}$. Also, copper may mediate free radical attack of amino acids, causing substantial protein alterations and even protein cleavage ${ }^{7}$.

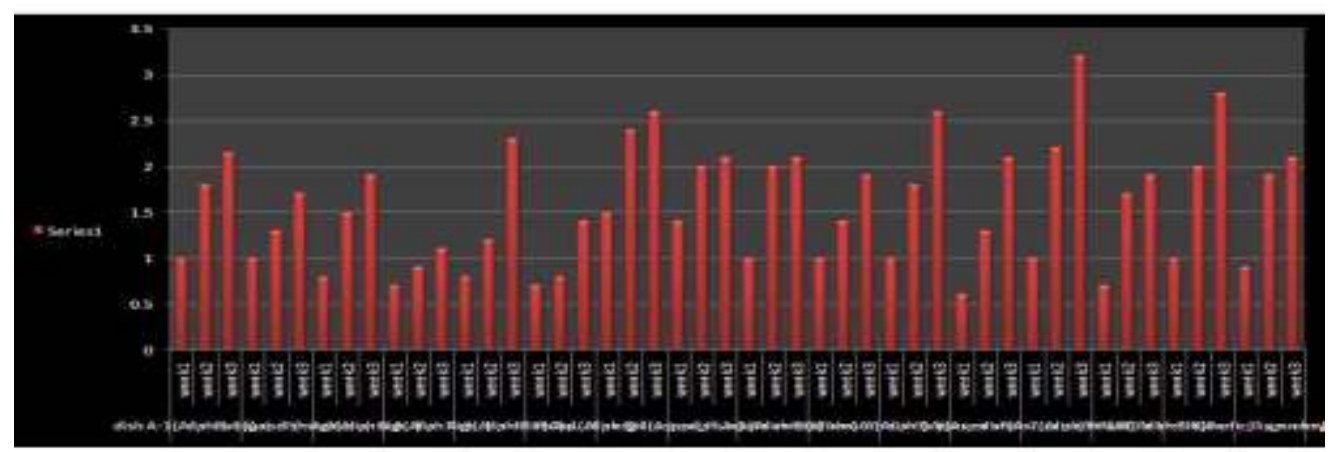

Fig(4) shows the growth of microbial species on dish plates in the absence and presence of bronze plates.

\section{3-3 Scanning electron microscope (SEM)}

Scanning electron microscope examination micrographs of external deteriorated bronze plate surface from the mummy of Djedptahiufankh showing that the original surface has been deformed by corrosive attacks such as pits, crevices, cracks and thin black lamellar corrosion as shown in Figure (5A). A thin black layer on the bronze surface would suggest the presence of sulphate ions which causes intensive corrosion. Copper can be described as the arrangement of copper atoms in a face-centered-cubic configuration as shown in Figure (5B). A copper atom is found at each corner and in the center of each face of a cube. This unit is repeated in three dimensional space to make up the crystal structure of the copper metal. The fragmentation or dendritic structures of the

7) Thurman, R.B. and Gerba, C.P., 1989. The Molecular Mechanisms of Copper and Silver Ion Disinfection of Bacteria and Viruses, CRC Critical Reviews in Environmental Control, Vol. 18, Issue 4, pp. 295-315.

8) Davies MJ, Gilbert BC, Haywood RM., 1991. Radical-induced damage to proteins: e.s.r. spin-trapping studies. Free Radic Res Commun,15: 111-27. 


\section{دراسات في آثار الوطن العربي بـ 1}

bronze layer commonly due to internal mechanical breakdown which results from internal stresses created by the decuprification process. The SEM microphotographs of the bronze surface revealed the presence of mechanical breakdown as deep cracks, intergranular corrosion and fragmentation as shown in Fig. (5C). Also, SEM micrographs of bronze plate surface usually in some parts appear as metallic ghost structures as a result of tin-enrichment corrosion layers due to copper depletion as a result of high content of chlorine ions in the corrosion bronze plate as shown in Fig. (5D).

\section{3-4 energy Dispersive X-Ray analysis (EDX)}

EDX microanalysis of three bronze samples from the mummy of Djedptahiufankh are essentially consists of $\mathrm{Cu}, \mathrm{Mg}, \mathrm{Al}, \mathrm{Si}, \mathrm{P}, \mathrm{S}, \mathrm{Cl}$,

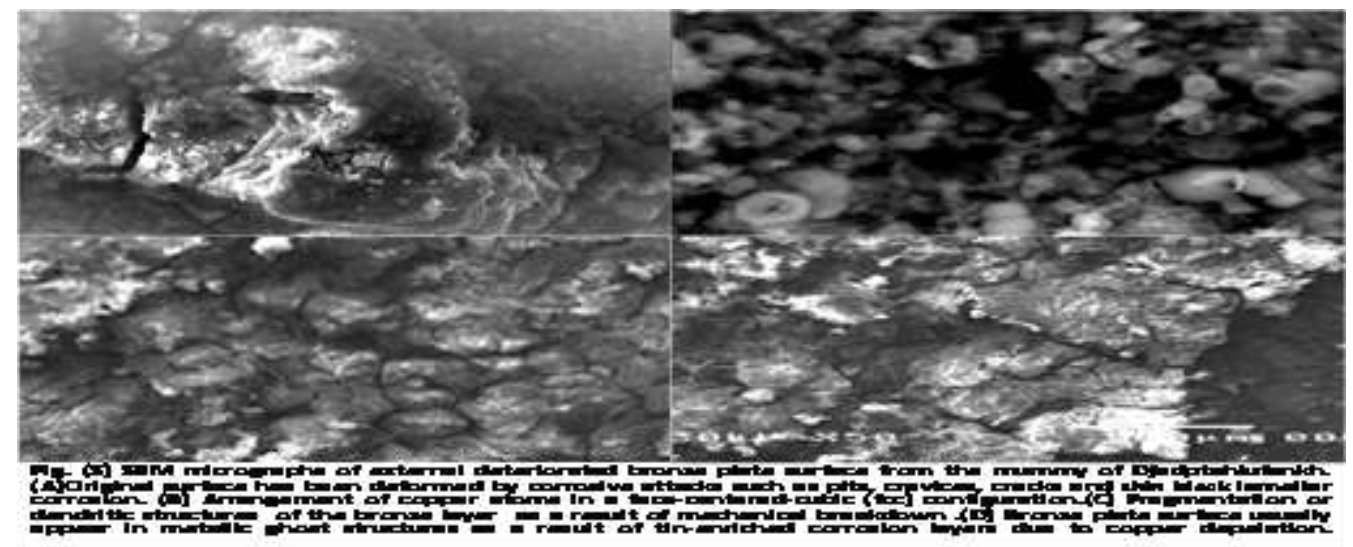

$\mathrm{Sn}, \mathrm{Ca}, \mathrm{Fe}$ and $\mathrm{Pb}$. These results in Table (2) reveal that there are some harmful elements such as chlorine and sulphate which already causes corrosive attack such as pits, crevices, cracks and thin black lamellar corrosion. 


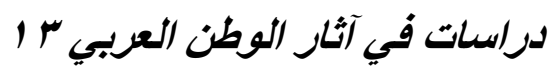

Table (2) Results of (EDX) Energy Dispersive X-Ray analysis of the bronze samples.

\begin{tabular}{|c|c|c|c|c|c|c|c|c|c|c|c|}
\hline $\begin{array}{c}\text { Mineral } \\
\text { compositio } \\
\text { n }\end{array}$ & $\mathrm{Cu}$ & $\mathrm{Mg}$ & $\mathrm{Al}$ & $\mathrm{Si}$ & $\mathrm{P}$ & $\mathrm{S}$ & $\mathrm{Cl}$ & $\mathrm{Sn}$ & $\mathrm{Ca}$ & $\mathrm{Fe}$ & $\mathrm{Pb}$ \\
\hline $\begin{array}{c}\text { sample (1) } \\
\text { from } \\
\text { bronz } \\
\text { plate }\end{array}$ & 73.9 & 0.1 & 0.1 & 0.6 & 0.4 & 0.6 & 5.0 & 16.6 & - & 2.8 & - \\
\hline $\begin{array}{c}\text { sample } \\
\mathbf{( 2 ) f r o m ~} \\
\text { bronze } \\
\text { plate }\end{array}$ & 79.4 & - & 0.1 & 0.6 & - & 1.2 & 5.0 & 12.2 & - & 1.2 & 0. \\
\hline $\begin{array}{c}\text { sample } \\
\text { (3)from } \\
\text { bronze } \\
\text { plate }\end{array}$ & 77.1 & 0.1 & - & 4.6 & 0.3 & 1.9 & 5.2 & 8.8 & 0.6 & 1.4 & - \\
\hline
\end{tabular}

The samples have high content of copper mineral range from $73.9 \%$ to $79.4 \%$ and tin mineral range from $8.8 \%$ to $16.6 \%$. The result analysis revealed that the ancient metal plate formed from tincopper alloy (bronze). Bronze is any alloy that is $85-95 \%$ copper, with the other $5-15 \%$ made up of mainly of tin or arsenic, though other metals can be present in small amounts. Most ancient copper alloys have less than $17 \%$ tin $^{8}$. In modern times bronze is strictly defined as consisting of $10-15 \%$ tin, but the ancient alloy was more variable in composition 9 . In the present studied Fe mineral content range from $1.2 \%$ to $2.8 \%$ and other minerals present in very small amount $(\mathrm{Ca}, \mathrm{Pb}, \mathrm{P}, \mathrm{Al}, \mathrm{Mg})$.

9) David A., 1991. Metallography and microstructure of ancient and historic metals., Published in association with Archetype Books by the Paul Getty Trust - Printed in Singapore Libraty of Congress Cataloguing

${ }^{10)}$ Lucas, A., 1962. Ancient Egyptian materials and industries. 4th ed revised and enlarged by JR Harris. London: Edward Arnold. 

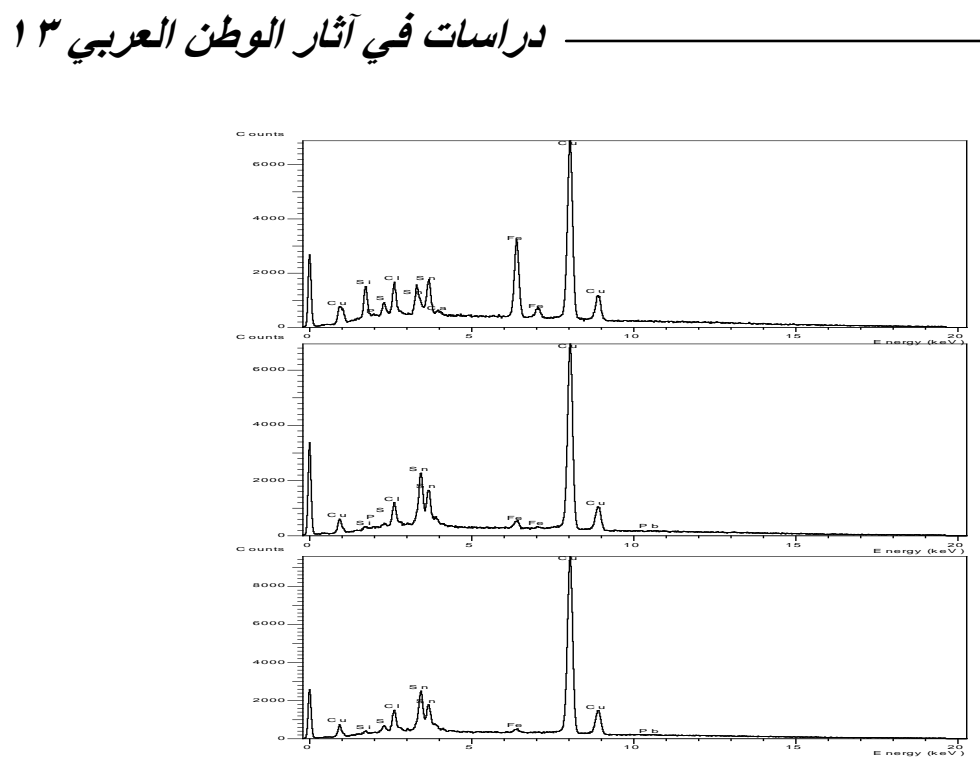

\section{EDX patterns of the studied sampl}

\section{3-5 X- Ray Diffraction analysis (XRD)}

One sample was taken from metal plate of the mummy of Djedptahiufankh. The results in Table (3) reveal that the metal plate sample consists of Copper, paratacamite, cuprite, cassiterite, truscottite and ferdisilicite. The scientific studied reveal that $\mathrm{CuO}$ (Neel EA. Et al., 2005) and copper alloys(Faundez G.et al., 2004; Noyco JO. et al., 2006; Wilks SA. et al., 2005) have potent biocidal properties, even against difficult bacterial spores ${ }^{10}$.

Bronze is represented mainly by copper and cassiterite minerals.

Cuprite is an oxide mineral composed of copper oxide $\mathrm{Cu}_{2} \mathrm{O}$ dispersed in the bronze plate indicates that the deterioration of bronze is primarily as a result of oxidation.

Paratacamite mineral formed as a result of chemical alteration of copper minerals by chloride ions under the cold condition (in high humidity). These results correspond to the EDX analysis and SEM micrographs.

${ }^{11)}$ Weaver L, Michels HT, Keevil CW., 2008. Survival of Clostridium difficile on copper and steel: futuristic options for hospital hygiene. J Hosp Infect 68: 145-51. 


\section{لدراسات في آثار الوطن العربي بـ 1}

Table (3) shows the Results of $\mathrm{X}$ - ray diffraction analysis of metal plate sample

\begin{tabular}{|c|c|c|c|}
\hline $\begin{array}{c}\text { Sample } \\
\text { No }\end{array}$ & Material type & $\begin{array}{c}\text { Sample } \\
\text { site }\end{array}$ & composition \\
\hline 1 & $\begin{array}{c}\text { Sample from the } \\
\text { mummy of } \\
\text { Djedptahiufankh }\end{array}$ & $\begin{array}{c}\text { Egyptian } \\
\text { museum }\end{array}$ & 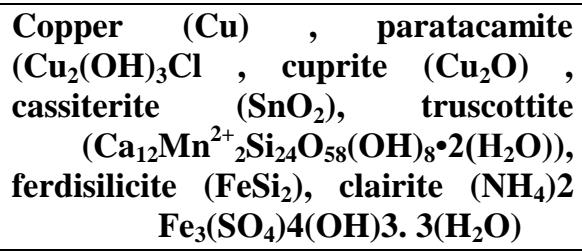 \\
\hline
\end{tabular}

The presence of ammonia, in combination with sulfate compounds on the copper surface represented by calairite mineral, indicates that the cause of corrosion of bronze plate could be mummification materials and/or surrounding soil during long burial of the mummy in the ground.

\section{Conclusion:}

1- The present study reveals that several kinds of bacteria and fungi, known in mummification science, die when placed on copper-tin alloy surfaces. The concentration of live bacteria drops from high orders to zero on copper-tin alloy in a few hours. Antimicrobial copper alloys surfaces kill greater than 99.9\% of bacteria within two hours, and continue to kill more than $99 \%$ of bacteria even after repeated contamination with copper". These public health claims acknowledge that copper, brass and bronze are capable of killing harmful, potentially deadly several bacteria, such as Methicillinresistant S. aureus (MRSA). MRSA is one of the most virulent strains of antibiotic-resistant bacteria ${ }^{11}$.

2- Several samples were taken under sterile conditions from Egyptian mummies. The results from previous biologic swabs reveal that several bacterial and fungal species were identified such as Asp. Niger, Asp. Fumigates, Asp. Flavus,

${ }^{12)}$ Borkow G, Gabbay J.,1991. Copper, an ancient remedy returning to fight microbial, fungal and viral infections. 3, 272-278. 


\section{راسات في آثار الوطن العربي}

Penicillium chrysogenum, Penicillium citrinum, Aspergillus japonicas, Asp. Wentii, Asp. Sulphureous and Pen. Citrinum.

3- The antibacterial activities of the copper-tin plates were tested by quantitative and qualitative methods. In absence of bronze plates the continuous growth of bacterial cells were observed while in presence of bronze plates the bacterial growth is suppressed to a great extent due to strong killing kinetic action of $\mathrm{Cu}$ II ions which released from bronze plates. Copper may damage many proteins, both on the microorganism envelope or within the cell, especially when found in high concentrations.

4- The mechanism of biocidal action of bronze plates may probably be explained on the basis of the fact that bronze plates release $\mathrm{Cu}$ (II) ions on contact with moisture. These copper ions bind with the $-\mathrm{SH}$ and $-\mathrm{COOH}$ groups of protein molecules of bacterial cell wall and destroyed them. In addition, copper exerts its toxicity to microorganisms through several parallel mechanisms, which eventually may lead to the microorganisms' death even within minutes of their exposure to copper ${ }^{12}$.

5- Scanning electron microscope micrographs of external deteriorated bronze plate surface showing several corrosive features such as pits, crevices, cracks, fragmentation, metallic ghost structures and thin black lamellar corrosion. A thin black layer attributed to the presence of sulphate ions which causes intensive corrosion. The fragmentation and metallic ghost structures of the bronze layer commonly due to internal

${ }^{13)}$ Ohsumi Y, Kitamoto K, Anraku Y.,1988.Changes induced in the permeability barrier of the yeast plasma membrane by cupric ion. J Bacteriol170: 2676-82. 


\section{هراسات في آثار الوطن العربي بـ 1}

mechanical breakdown which results from internal stresses created by the copper depletion and corrosive attack by chlorine ions.

6- The EDX analysis reveal that the samples have high content of copper mineral range from $73.9 \%$ to $79.4 \%$ and tin mineral range from $8.8 \%$ to $16.6 \%$ while, the XRD analysis reveal that the plate sample consists of Copper, paratacamite, cuprite, cassiterite, truscottite and ferdisilicite. From EDX and XRD analysis we can suggest that the plate samples from copper-tin alloy (bronze). Moreover, the results refer to presence of ammonia, in combination with sulfate compounds on the copper surface. These results indicate that the cause of corrosion of bronze plate may be mummification materials and/or surrounding soil during long burial of the mummy in the ground.

\section{Author reading}

1. Belli N, Marin S, Sanchis V, Ramos AJ., 2006. Impact of fungicides on

Aspergillus carbonarius growth and ochratoxin A production on synthetic grape-like medium and on grapes. Food Addit Contam 23: 1021-9.

2. Benns BG, Gingras BA, Bayley CH., 1960.Antifungal Activity of Some

Thiosemicarbazones and Their Copper Complexes. Appl Microbiol

8: 353-6. 
3. Borkow G, Sidwell RW, Smee DF, et al., 2007.Neutralizing viruses in suspensions by copper oxide based filters. Antimicrob Agents Chemother 51: 2605-7.

4. Davies MJ, Gilbert BC, Haywood RM., 1991. Radicalinduced damage to proteins: e.s.r. spin-trapping studies. Free Radic Res Commun, 15: 111-27.

5. Dean RT, Wolff SP, McElligott MA., 1989.Histidine and proline are important sites of free radical damage to proteins. Free Radic Res

Commun, 7: 97-103.

6. Dollwet HHA, Sorenson JRJ., 2001. Historic uses of copper compounds

in medicine. Trace Elements Med 2: 80-7.

7. Espirito SC, Taudte N, Nies DH, Grass G., 2008. Contribution of copper ion resistance to survival of Escherichia coli on metallic copper surfaces. Appl Environ Microbiol 74: 977-86.

8. Faundez G, Troncoso M, Navarrete P, FiguerG., 2004. Antimicr- obial activity of copper surfaces against suspensions of Salmonella enterica and Campylobacter jejuni. BMC Microbiol 4: 1925.

9. Foye Wo, Van De Workeen IB Jr, Matthes JD.,1958.Copper complexes of aromatic dithiocarbamates and their antifungal activity. $\mathrm{J}$ Am Pharm Assoc Am Pharm Assoc (Baltim) 47: 556-8.

10.Lucas, A., 1962. Ancient Egyptian materials and industries. 4th ed revised and enlarged by JR Harris. London: Edward Arnold. 
11.Neel EA, Ahmed I, Pratten J, Nazhat SN, Knowles JC., 2005.Characterisation of antibacterial copper releasing degradable phosphate glass fibres. Biomaterials 26: 2247-54.

12.Noyce JO, Michels H, Keevil CW., 2006. Use of copper cast alloys to control Escherichia coli O157 cross-contamination during food

13.processing. Appl Environ Microbiol 72: 4239-44.

14.Ohsumi Y, Kitamoto K, Anraku Y.,1988.Changes induced in the permeability barrier of the yeast plasma membrane by cupric ion. J Bacteriol170: 2676-82.

15.Resistant Roofing System, 2004.http:// solutions.3m. com/ wps/por-tal/3M/en_US/IMPD/RoofingSolutions/Products/Scotchgard-Algae- Resistant.

16.Scigliano JA, Grubb TC, Shay DE., 1950. Fungicidal testing of some organocopper compounds. J Am Pharm Assoc Am Pharm Assoc39: 673-6.

17.Thurman, R.B. and Gerba, C.P., 1989. The Molecular Mechanisms of Copper and Silver Ion Disinfection of Bacteria and Viruses, CRC Critical Reviews in Environmental Control, Vol. 18, Issue 4, pp. 295-315.

18.Weaver L, Michels HT, Keevil CW., 2008. Survival of Clostridium difficile on copper and steel: futuristic options for hospital hygiene. J Hosp Infect 68: 145-51.

19.Wilks SA, Michels H, Keevil CW., 2005. The survival of Escherichia coli $\mathrm{O} 157$ on a range of metal surfaces. Int J Food Microbiol 105. 